\title{
Bioelectrochemical Characterization of Heavy Metals Resistant yeast: Hansenula fabianii Isolated from Tannery Wastewater
}

\author{
Alae Elabed ${ }^{1.2}$, Loubna Ezziat ${ }^{2}$, Saad Ibnsouda ${ }^{1.4}$, Soumya Elabed ${ }^{4}$, Benjamin Erable ${ }^{1}$ \\ ${ }^{1}$ Laboratoire de Génie Chimique, Université de Toulouse, CNRS, INPT, UPS, Toulouse, France \\ ${ }^{2}$ Laboratoire de Biotechnologie Microbienne, Faculté des Sciences et Techniques, Université Sidi \\ Mohamed Ben Abdellah, Fès, Maroc \\ ${ }^{3}$ Laboratoire de Science et Technologie du Génie des procédés, Université Sidi Mohamed Ben \\ Abdellah, Fès, Maroc \\ ${ }^{4}$ Cité d'Innovation, Université Sidi Mohamed Ben Abdellah- Fès, Maroc \\ *E-mail: soumya.elabed@usmba.ac.ma
}

doi: $10.20964 / 2021.01 .31$

Received: 10 January 2020/ Accepted: 9 June 2020 / Published: 30 November 2020

To date, heavy metals present a main drawback for bioelectrochemical systems (BESs) performances. Therefore, our results confirm, for the first time, that Hansenulafabianii is an electrochemical active yeast that has a potential tolerance against various heavy metals. The bioreactor inoculated by Hansenula fabianii in mediatoless conditions provided a maximum current density of $32 \mathrm{~mA} / \mathrm{m}^{2}$; up to $300 \mathrm{~mA} / \mathrm{m}^{2}$ in the presence of methylene blue. In mediatorless conditions, cyclic voltammetry $(\mathrm{CV})$ on a yeast pellet showed a single oxidative peak at $450 \mathrm{mV}$ and a pair peak, the $\mathrm{CV}$ of the supernatant confirmed that Hansenula fabianii secretedits own mediator. The obtained results proved that Hansenula fabianii based biofuel cell could be used for simultaneous current generation and heavy metal bioremediation.

Keywords: Electrochemical active yeast; heavy metals; Hansenula fabianii; mediatorless condition.

\section{$\underline{\text { FULL TEXT }}$}

(C) 2021 The Authors. Published by ESG (www.electrochemsci.org). This article is an open access article distributed under the terms and conditions of the Creative Commons Attribution license (http://creativecommons.org/licenses/by/4.0/). 